\title{
ISOLASI DAN KARAKTERISASI Beauveria bassiana SEBAGAI FUNGI ANTI HAMA
}

\author{
Eka Sari ${ }^{1}$, Zulvia Intan Sari ${ }^{2}$, Anggi Nico Flatian ${ }^{2}$, Eman Sulaeman ${ }^{2}$ \\ ${ }^{1}$ Jurusan Biologi, Universitas Bangka Belitung, Bangka, Indonesia \\ "Corresponding author: ekasari090@gmail.com \\ ${ }^{2}$ Departemen Imu Tanah dan Sumberdaya Lahan, Institut Pertanian Bogor
}

\begin{abstract}
Development of biological potential could to be a solution of pest problems and environmental damage by pesticides. One of the organisms that are currently often be used for biopesticides is the entomopathogenic fungi such as Beauveria brassiana. This study aim to isolate, characterize of pest-resistant fungi and apply it to some agricultural insect pests in vitro. Samples which used were planthoppers, aphids, grasshoppers and isolated fungi Beauveria bassiana from Biogen Laboratory. The research was conducted in Soil and Environmental Biotechnology Laboratory, Dramaga, Bogor. Isolation method with Insect Bait Methode. Isolation and characterization of pest-resistant fungi that are planthoppers and aphids show the result that the great possibilities are the Beauveria bassiana fungus, that is clearly visible from the obtained physical characteristics, the white and sealed hyphae and conidia round oval. In addition, the fungi which used is a pathogenic fungi on the pest of aphids, planthoppers, and grasshoppers.
\end{abstract}

Keywords: Beauveria bassiana, pest-resistant fungi.

\section{PENDAHULUAN}

Tumbuhan secara umum maupun pertanian secara khusus tidak selamanya bisa hidup tanpa gangguan. Kadang tumbuhan mengalami gangguan oleh binatang atau organisme kecil (virus, bakteri, atau jamur). Hewan dapat disebut hama karena mereka mengganggu tumbuhan dengan memakannya. Belalang, kumbang, ulat, wereng, tikus, walang sangit merupakan beberapa contoh binatang yang sering menjadi hama tanaman. Gangguan terhadap tumbuhan yang disebabkan oleh virus, bakteri, dan jamur disebut penyakit. Tidak seperti hama, penyakit tidak memakan tumbuhan, tetapi mereka merusak tumbuhan dengan mengganggu proses dalam tubuh tumbuhan sehingga mematikan tumbuhan.

Dahulu, pada umumnya orang-orang akan menggunakan pestisida sebagai solusi untuk membasmi hama pada pertanian. Namun, penggunaan pestisida kimia pada akhirnya malah menjadi masalah baru saat ini. Hal itu disebabkan karena selain merusak lingkungan, pestisida dapat menimbulkan kekebalan pada hama dan penyakit. Oleh karena itu pengguna obat-obatan anti hama dan penyakit hendaknya diusahakan seminimal dan sebijak mungkin. Secara alamiah, sesungguhnya hama mempunyai musuh yang dapat mengendalikannya. Namun, karena ulah manusia, sering kali musuh alamiah hama hilang. Akibat hama tersebut merajalela.

Menurut Untung (2003), pada suatu saat populasi hama sekunder dapat meningkat melebihi batas toleransi tanaman. Peningkatan ini disebabkan karena gangguan proses pengendalian alami, keadaan iklim yang tidak menentu, atau kesalahan pengendalian oleh manusia. Satu jenis serangga dalam kondisi tempat dan waktu tertentu dapat berubah status, misalnya hama wereng batang padi coklat sebelum tahun 1970 hanya dianggap sebagai hama potensial, tetapi kemudian karena adanya perubahan cara budidaya tanaman padi, setelah tahun 1970 berubah menjadi hama utama padi di Indonesia.

Selain dari penggunaan pestisida kimia yang terakumulasi di lingkungan dan seringkali malah menjadi permasalahan baru, saat ini para peneliti mulai mengembangkan potensi hayati untuk dapat menjadi solusi atau jalan tengah dari permasalahan hama dan kerusakan lingkungan oleh pestisida. Salah satu organisme yang saat ini sering digunakan untuk dijadikan biopestisida adalah fungi kelompok entomopatogen seperti Beauveria brassiana. Adapun tujuan dilakukannya penelitian ini adalah untuk mengisolasi, mengarakterisasi fungi anti hama dan mengaplikasikannya pada beberapa serangga hama pertanian secara in vitro.

\section{METODE PENELITIAN}

\section{Pengambilan Sampel}

Sampel wereng diambil di Kebun Percobaan Muara, Balai Penelitian Tanaman Padi, Bogor. Walang sangit diambil di rumah kaca Balai Penelitian Bioteknologi di Cimanggu. Satu isolat fungi Beauveria bassiana dari Laboratorium Biogen. Belalang dari sekitar kampus IPB, Bogor. Penelitian dilaksanakan di Laboratorium Bioteknologi Tanah dan Lingkungan, Dramaga, Bogor.

\section{Bahan dan Alat}

Bahan yang digunakan, terdiri dari: kertas saring, aquadest, kertas saring steril, media PDA, natrium hipoklorit $1 \%$, serangga, tissue. Alat yang digunakan 
terdiri dari: autoklaf, pembakar spiritus, kaca objek, kaca penutup, kertas label, penjepit, timbangan, ose, cawan petri, sprayer alkohol 1 buah, vortex, inkubator, laminar air flow (LAF) dan oven

\section{Metode}

\section{Isolasi B. bassiana}

Isolasi B. bassiana dengan Insect Bait Method, yaitu:

1. Serangga (jangkrik, kumbang, semut merah ataupun belalang) dimasukkan ke dalam tanah yang berisi tanah sampel sebagai perangkap umpan agar terserang jamur $B$. bassiana.

2. Serangga yang diduga terserang jamur B. bassiana diamati 3 hari setelah diperlakukan kemudian diamati setiap harinya dan segera setelah terserang jamur $B$. bassiana diisolasi sebagai sumber isolat.

3. Serangga yang terinfeksi jamur $B$. bassiana terlebih dahulu disterilisasi permukaan dengan 1\% Natrium hipoklorit selama 3 menit.

4. Bilas dengan air steril sebanyak 3 kali dan dikering anginkan diatas kertas filter steril.

5. Serangga kemudian diletakkan dalam petridish berisi tissu lembab steril dan diinkubasikan untuk merangsang pertumbuhan jamur.

6. Spora yang keluar dari tubuhnya kemudian diambil menggunakan ose dan dibiakkan pada Potato Dextrose Agar (PDA) kemudian diinkubasikan selama 7 hari.

\section{Pengamatan morfologi}

Satu ose fungi dioleskan ke kaca objek, lalu ditambahkan sedikt aquades, dan diamati dibawah mikroskop. Hasil pengamatan dicatat dan didokumentasikan

\section{Uji infeksi fungi anti hama terhadap serangga}

Fungi anti hama diambilkan 1 ose dan dimasukkan ke dalam media yang sudah diisikan serangga dengan jarak agak jauh, kemudian diinkubasi. Uji positif einfeksi anti hama dilihat jika fungi menutupi tubuh serangga.

\section{HASIL DAN PEMBAHASAN}

\section{Hasil}

Pengamatan morfologi fungi anti hama dilakukan pada fungi dari walang sangit, wereng, dan fungi Biogen yang dilihat dari hifa fungi yang mampu menginfeksi walang sangit, wereng dan belalang (Tabel ). Walang sangit dan wereng yang sudah disterilisasikan, kemudian diinkubasi beberapa hari (Gambar 1), kemudian setelah beberapa hari di sekitar tubuh walang sangit dang wereng ditumbuhi oleh fungi (Gambar 2). Hifa fungi baik dari wereng maupun walang sangit berwarna putih (Gambar 3). Pengamatan morfologi di bawah mikroskop memperlihatkan sekat, konidia dan hifa hyalin (Gambar 4). Hasil uji positif infeksi fungi anti hama terhadap serangga, seperti walang sangit, wereng dan belalang ditunjukkan oleh hifa yang menginfeksi serangga tersebut (Gambar 5).

Tabel 1. Hasil pengamatan fungi pada walang sangit, wereng dan fungi Biogen

\begin{tabular}{llll}
\multicolumn{1}{c}{ Pengamatan } & \multicolumn{1}{c}{ Walang Sangit } & \multicolumn{1}{c}{ Wereng } & Biogen \\
\hline $\begin{array}{l}\text { Pengamatan Inkubasi } \\
\text { Serangga }\end{array}$ & $\begin{array}{l}\text { Mulai terlihat hifa disekitar tubuh } \\
\text { serangga }\end{array}$ & $\begin{array}{l}\text { Mulai terlihat hifa } \\
\text { disekitar tubuh } \\
\text { serangga }\end{array}$ & Isolat yang sudah ada \\
\hline $\begin{array}{l}\text { Isolasi Fungi } \\
\text { entomopatogen }\end{array}$ & $\begin{array}{l}\text { Fungi pada tubuh serangga diisolasi } \\
\text { pada media PDA dalam petridisk }\end{array}$ & $\begin{array}{l}\text { Fungi pada tubuh } \\
\text { serangga diisolasi } \\
\text { pada media PDA } \\
\text { dalam petridisk }\end{array}$ & $\begin{array}{l}\text { Fungi pada tubuh } \\
\text { serangga diisolasi pada } \\
\text { media PDA dalam } \\
\text { petridisk }\end{array}$ \\
\hline $\begin{array}{l}\text { Pengamatan Isolasi } \\
\text { pertama }\end{array}$ & $\begin{array}{l}\text { Belum terlihat tanda-tanda } \\
\text { pertumbuhan fungi }\end{array}$ & $\begin{array}{l}\text { Belum terlihat tanda- } \\
\text { tanda pertumbuhan } \\
\text { fungi }\end{array}$ & $\begin{array}{l}\text { Belum terlihat tanda- } \\
\text { tanda pertumbuhan } \\
\text { fungi }\end{array}$ \\
\hline $\begin{array}{l}\text { Pengamatan Isolasi } \\
\text { kedua }\end{array}$ & $\begin{array}{l}\text { Mulai terlihat pertumbuhan fungi } \\
\text { meski masih sangat kecil }\end{array}$ & $\begin{array}{l}\text { Mulai terlihat } \\
\text { pertumbuhan fungi } \\
\text { meski masih sangat } \\
\text { kecil }\end{array}$ & $\begin{array}{l}\text { Belum terlihat tanda- } \\
\text { tanda pertumbuhan } \\
\text { fungi }\end{array}$ \\
\hline $\begin{array}{l}\text { Pengamatan isolasi } \\
\text { ketiga }\end{array}$ & $\begin{array}{l}\text { Hifa semakin jelas terlihat dengan } \\
\text { karakteristik putih }\end{array}$ & $\begin{array}{l}\text { Hifa semakin jelas } \\
\text { terlihat }\end{array}$ & $\begin{array}{l}\text { Hifa semakin jelas } \\
\text { terlihat }\end{array}$ \\
\hline $\begin{array}{l}\text { Pemurnian Fungi } \\
\text { Entomopatogen }\end{array}$ & $\begin{array}{l}\text { Dari isolat yang ada dilakukan } \\
\text { isolasi kembali }\end{array}$ & $\begin{array}{l}\text { Dari isolat yang ada } \\
\text { dilakukan isolasi } \\
\text { kembali }\end{array}$ & $\begin{array}{l}\text { Dari isolat yang ada } \\
\text { dilakukan isolasi } \\
\text { kembali }\end{array}$ \\
\hline $\begin{array}{l}\text { Pemurnian Fungi } \\
\text { Entomopatogen }\end{array}$ & $\begin{array}{l}\text { Pemurnian sebelumnya positif dan } \\
\text { kembali diisolasi ke petridisk }\end{array}$ & $\begin{array}{l}\text { Pemurnian } \\
\text { sebelumnya positif } \\
\text { dan kembali diisolasi } \\
\text { ke petridisk }\end{array}$ & $\begin{array}{l}\text { Pemurnian sebelumnya } \\
\text { positif dan kembali } \\
\text { diisolasi ke petridisk }\end{array}$ \\
\hline
\end{tabular}




\begin{tabular}{llll}
\hline & & $\begin{array}{l}\text { Pengamatan hifa di } \\
\text { bawah mikroskop dan } \\
\text { pemurnian kembali } \\
\text { untuk digunakan } \\
\text { Pengamatan hifa di bawah }\end{array}$ & $\begin{array}{l}\text { Pengamatan hifa di } \\
\text { bawah mikroskop dan } \\
\text { pemurnian kembali } \\
\text { untuk digunakan }\end{array}$ \\
$\begin{array}{l}\text { Pengamatan dan } \\
\text { Pemurnian Fungi } \\
\text { Entomopatogen }\end{array}$ & $\begin{array}{l}\text { untuk digunakan sebagai bahan } \\
\text { penguji pada serangga. Terlihat } \\
\text { konidia hialin berbentuk bulat } \\
\text { lonjong dengan hifa putih dan } \\
\text { bersekat. }\end{array}$ & $\begin{array}{l}\text { penguji pada } \\
\text { serangga. Terlihat } \\
\text { konidia hialin }\end{array}$ & $\begin{array}{l}\text { konidia hialin } \\
\text { pada serangga. Terlihat } \\
\text { berbentuk bulat } \\
\text { berbentuk bulat }\end{array}$ \\
& & $\begin{array}{l}\text { lonjong dengan hifa } \\
\text { putih. Bersekat. }\end{array}$ & $\begin{array}{l}\text { putih. Hifa putih } \\
\text { bersekat. }\end{array}$ \\
\hline $\begin{array}{l}\text { Pengujian Pada } \\
\text { Wereng, Walang }\end{array}$ & Serangga mati dengan tubuh & $\begin{array}{l}\text { Serangga mati } \\
\text { dengan tubuh }\end{array}$ & $\begin{array}{l}\text { Serangga mati dengan } \\
\text { tubuh diselaputi hifa }\end{array}$ \\
Sangit dan Belalang & diselaputi hifa fungi & & \\
\hline
\end{tabular}

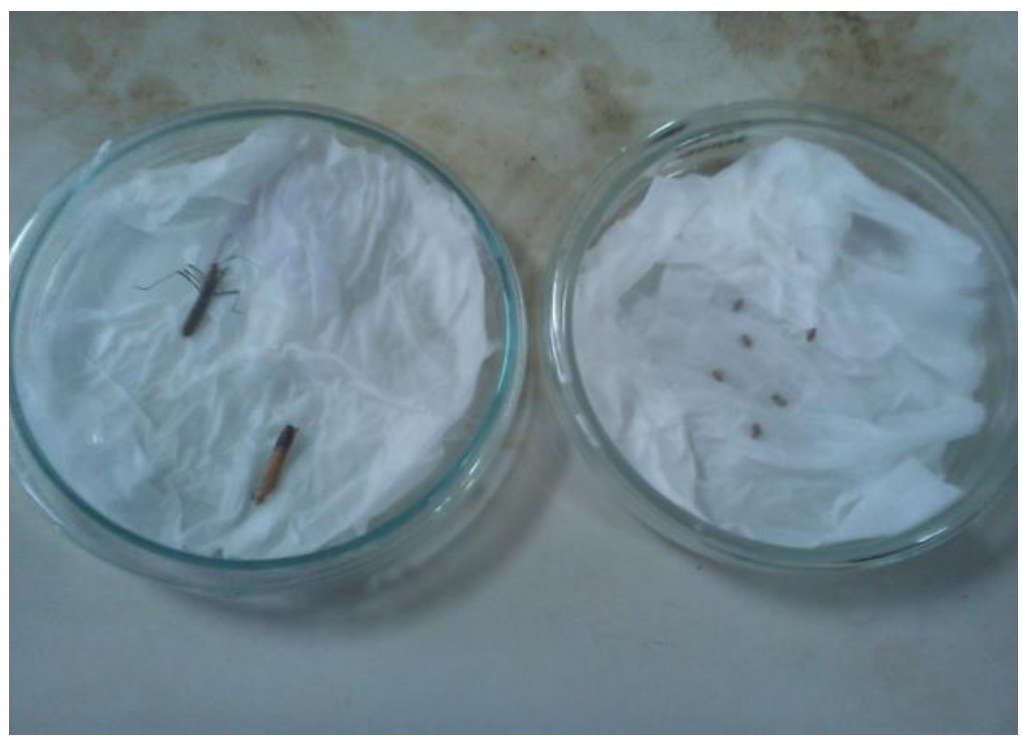

Gambar 1. Walang sangit dan wereng sebelum inkubasi

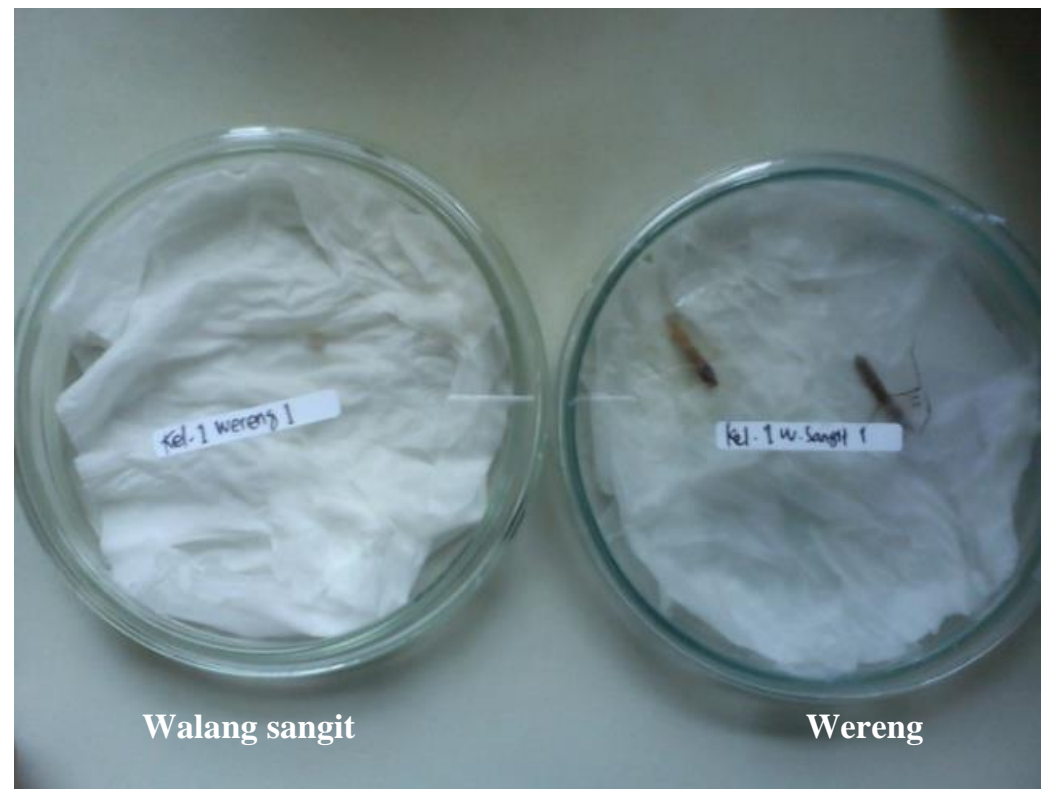

Gambar 2. Walang sangit dan wereng yang telah diselubungi hifa fungi 


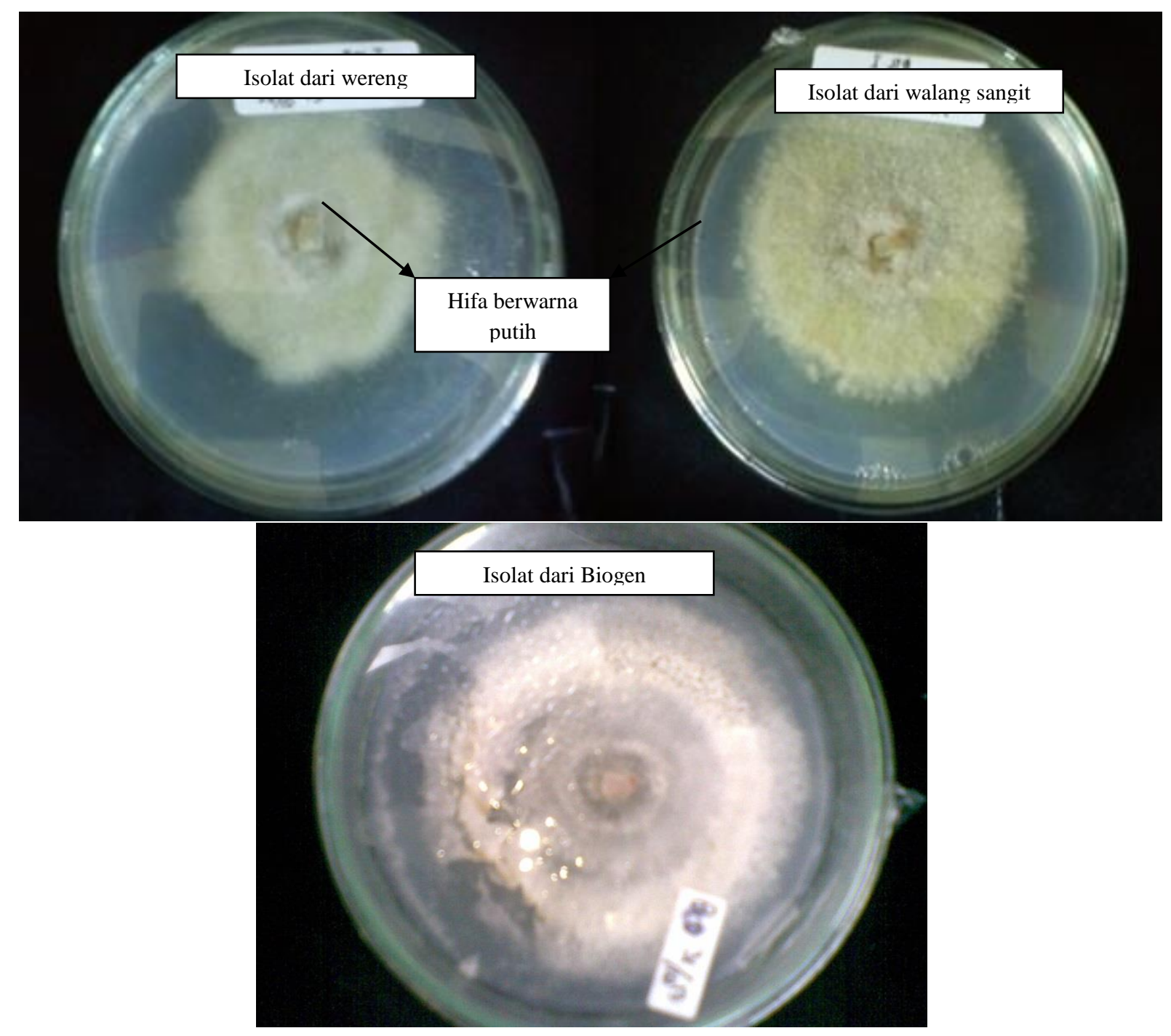

Gambar 3. Isolat Fungi entomopatogen dengan ciri-ciri yang menyerupai $B$. brassiana

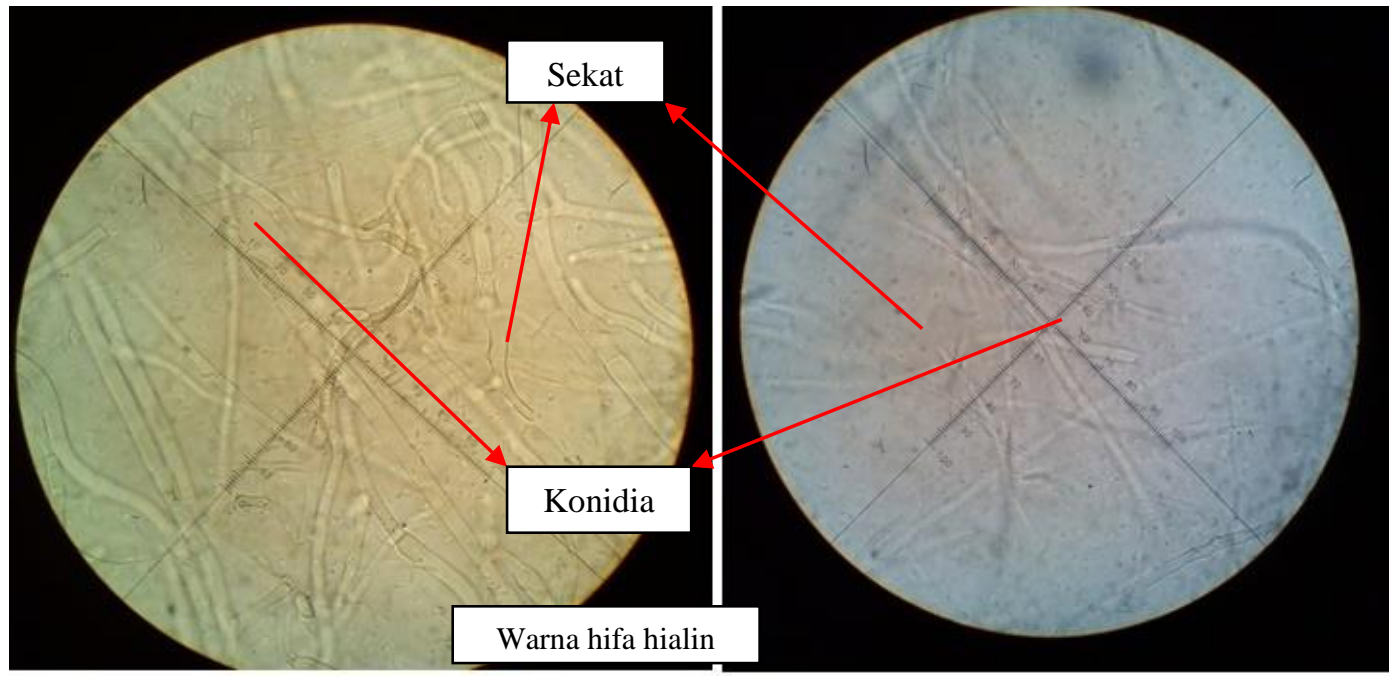

Gambar 4. Hasil pengamafatan fungi di bawah mikroskop cahaya perbesaran $1000 \mathrm{x}$ 


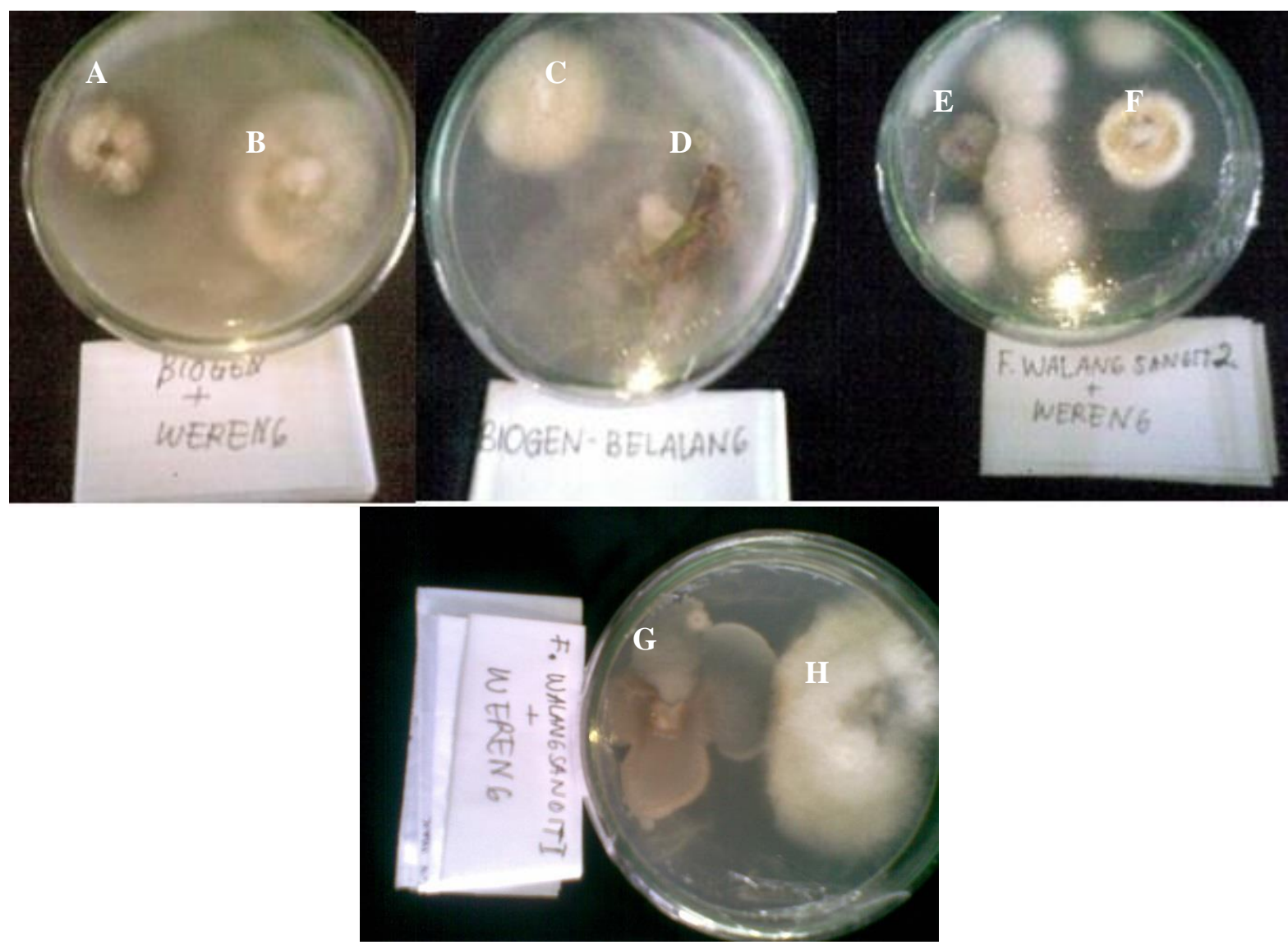

Gambar 5. Hasi uji positif infeksi fungi anti hama terhadap serangga. A). wereng; B). fungi asal Biogen; C). fungi asal biogen; D). belalang; E). wereng; F). Fungi asal walang sangit 2; G). Wereng; H). fungi asal walang sangit 1

\section{Pembahasan}

Fungi anti hama yang digunakan pada praktikum ini diisolasi dari hama yang telah mati dan diinkubasi selama lebih kurang empat hari. Hama yang telah mati yang digunakan adalah wereng dan walang sangit. Selain menggunakan fungi yang berasal dari hama serangga yang mati, juga digunakan isolat biogen yang sudah ada. Serangga yang mati sebelumnya di sterilisasikan kedalam larutan natrium Hipoklorit dan dibilas dengan aquades steril. Setelah diangin-anginkan agar cukup kering, serangga di masukkan kedalam petridisk yang telah dilapisi tidu lembab steril, kemudian dilakukan inkubasi untuk merangasang pertumbuhan jamur. Pada hari pertama dan kedua, hifa jamur belum terlalu kelihatan. Namun pada hari ketiga dan seterusnya hifa jamur mulai terlihat menyelubungi serangga yang mati tersebut.

Langkah selanjutnya adalah dilakukan pembuatan medium PDA dan sekaligus sterilisasi medium kedalam autoklaf, dan dilakukan isolasi fungi pada media tersebut. Pada pengamatan pertama, yakni tiga hari setelah dilakukan isolasi, belum terlihat tanda-tanda pertumbuhan fungi dalam media, kemudian kembali diinkubasi selama beberapa hari. Pengamatan selanjutnya dilakukan keesokan harinya, dan terlihat pada petridisk mulai ada pertumbuhan dari fungi meski masih kecil dan hifa belum terlihat jelas. Isolat kembali diinkubasi. Pada pengamatan ketiga, hifa pada ketiga sampel mulai terlihat jelas. Dari pengamatan ini dicatat ciri morfologis dari fungi yang tumbuh. Hifa berwarna putih dengan koloni berbentuk lingkaran.

Hasil pemurnian fungi yang tumbuh jauh lebih banyak ditandai dengan terlihatnya hifa putih yang lebih banyak dengan lingakaran koloni yang lebih besar. Dari isolat hasil pemurnian ini dilakukan pengamatan selanjutnya dibawah mikroskop untuk melihat bentuk hifa dan konidia pada fungi. Terlihat bentuk hifa berwarna putih dan bersekat dengan konidia bulat lonjong. Pengamatan di bawah mikroskop menggunakan pembesaran lensa objektif sebesar 4x, 10x, 40x, dan 100x. Selain itu, dari isolat ini juga dilakukan pemurnian kembali dimana hasil pemurnian kembali digunakan pada uji fungi ke serangga hama.

Dari hasil pengamatan ciri morfologis fungi baik dari bentuk hifa dan konidia dapat diperkirakan bahwa fungi ini adalah Beauveria brassiana. Menurut Tanada (1987), Konidiofor berbentuk zigzag dan pada ujungnya membentuk konidia. Konidia hialin bulat lonjong terdiri atas satu sel kering dan kecil menonjol. Hifa hialin pun bersekat. Miselium berwarna putih dengan penampakan seperti tepung 
dan membentuk gelembung pada pangkalnya serta berkelompok. Dari membandingkan ciri-ciri yang ada dengan literatur yang tersedia dapat diperkirakan bahwa fungi yang digunakan pada praktikum ini adalah $B$. brassiana.

Tahapan berikutnya, yaitu dilakukan pengujian pada hama serangga wereng, walang sangit dan belalang. Hasilnya menunjukkan serangga positif terinfeksi fungi anti hama, karena terlihat hifa-hifa yang berwarna putih yang menyelubungi tubuh ketiga serangga tersebut. Hifa terlihat muncul pertama-tama disekat tubuh serangga (terlihat lebih jelas pada belalang), kemudian baru menyelimuti bagian tubuh yang lain. Menurut Susanto (2006), jamur $B$. bassiana mampu menghasilkan konsentrasi enzim dan toksin yang cukup tinggi yang dapat menguraikan dan menghancurkan struktur tubuh belalang. $B$. bassiana juga menghasilkan senyawa toksin, seperti: beauvericin, enniatins, bassianolide, cyclosporins A dan C dengan sifat insektisida (Roberts, 1981; Weiser \& Matha, 1988;. Weiser et al., 1989; Wraight \& Ramos, 2005). Beauvercin yang dihasilkan mampu memperlemah sistem kekebalan inang. Spora jamur yang mengenai integumen akan segera berkecambah dan membentuk hifa yang panjang dan pendek. Hifa yang panjang dapat segera menembus integumen dan menginfeksi alat-alat vital serangga sehingga dapat mematikan, sedangkan hifa yang pendek dapat masuk melalui spirakel langsung ke dalam siste trakea dan menghasilkan racun beauvericin yang akan merusak struktur membran sel akibat dehidrasi yang akhirnya mematikan serangga sasaran (Sila, 1983 dalam Astuti, 2008).

\section{KESIMPULAN}

Hasil isolasi dan karakterisasi fungi anti hama dari serangga yaitu wereng dan walang sangit kemugkinan besar adalah Beauveria bassiana. Hal ini didasarkan pada ciri-ciri fisik yang didapat, yaitu hifa berwarna putih dan bersekat serta konidia bulat lonjong. Selain itu fungi yang digunakan merupakan fungi patogen pada hama walang sangit, wereng, dan belalang.

\section{REFERENSI}

Arif A., Muin M., Kuswinanti T. dan Rahmawati. 2008. Isolasi Dan Identifikasi Jamur Kayu Dari Hutan Pendidikan Universitas Hasanuddin Di Bengo-Bengo Kecamatan Cenrana Kabupaten Maros. Universitas Hasanuddin: Makasar.

Susanto A., Herdiana R., Rasiska S. dan Proklamasiningsih E. 2006. Konsentrasi Efektif Jamur Entomopatogen Beauveria Bassiana (Balsamo) Vuillemin Isolat Subang Terhadap Nimfa Belalang Daun Padi Oxya Sp. (Orthoptera: Acrididae) di Rumah Kaca. Universitas Padjadjaran: Bandung

Tanada Y. 1987. Microbial Pesticide Pest Control. Academic Press: New York, San Fransisco, London.
Untung K. 1993. Pengantar Pengelolaan Hama Terpadu. Yogyakarta: Gadjah Mada University Press.

Weiser J. and Matha V. 1988. The insecticidal activity of cyclosporines on mosquito larvae. Journal of Invertebrate Pathology. 51:92-93.

Weiser J., Matha V., Zizka Z. and Jegorov A. 1989. Pathology of cyclosporin A in mosquito larvae. Cytobios. 59:143-150.

Wraight S.P. and Ramos M.E. 2005. Synergistic interaction between Beauveria bassiana-and Bacillus thuringiensis tenebrionis-based biopesticides applied against field populations of Colorado potato beetle larvae. Journal of Invertebrate Pathology. 90:139-150. 